\title{
Adaptation as a Means of Translation
}

\author{
Dr. Tareq Ali Eadaroos Assaqaf \\ Assistant Professor, English Department, Faculty of Education-Saber, University of Aden, Lecturer at the English and Translation \\ Department, Faculty of Sciences and Arts, University of Jeddah
}

\begin{abstract}
This paper briefly discussed relation between Adaption and translation, it is well-known that translation theorists around the world did not arrive to a complete agreement about the definition of the term translation that can be applied to all languages of the world, since every one of them delivers a definition that coordinates with his / her own language and culture. The basic reason of this, in my point of view, is that all languages are different and have different rules and not every single vocabulary in one language has a single ready-made equivalent in the other language and herein lies the importance of the availability of the technique of adaptation during the process of translating from one language into another.
\end{abstract}

Keywords: Adaption, Translation, Relations

\section{Introduction}

There is an interesting saying between translations theorists around the world says that translation is like a woman: if it is faithful, it is not beautiful, if it is beautiful, it is not faithful. Of course the faithfulness-beauty trend cannot be achieved $100 \%$ in translation and interpretation as well, that is why both translators and interpreters coerce to use the technique of adaptation.

This paper attempts to investigate why adaptation is frequently needed and also it enumerates the types of adaptation translators and interpreters make in their work.

\section{Adaptation as a Means of Translation}

I define adaptation as a type of translation which involves a number of changes to be made so that the target text produced be in harmony with the spirit of the source text. These changes are of various types. They are: deletion, addition, explanation, illustration and exemplification.

For example, Newmark (1995) in his definition focuses on translating the author's intention. He defines translation as "rendering the meaning of a text into another language in the way that the author intended the text". But Nida and Taber (1982) in their definition focus on the meaning and style and use the term "reproduction" to indicate to the process of translation. To quote them: "Translation is the reproduction in a receptor language of the closest natural equivalent of the source language message, first in terms of meaning, and secondly in terms of style. Shi (2003) a Chinese translation theorist, assures that communicative translation needs what he calls "accommodation" which involves making a number of changes that are needed for the target text in order to be in line with the essence of the source text. To quote him: "We believe translation is not merely linguistic conversion or transformation between languages but it involves accommodation in scope of culture, politics, aesthetics and many other factors".

Though each previous definition refers to the process of translation from a different dilemma, all of them agree that the process, by one way or another, involves a number of changes.
These changes have to be in harmony with the target text culture provided it does not maim or distort the meaning of the source language since it must be the main goal.

\section{Types of Adaptation}

In my point of view there are four basic types of adaptation. They are: collocation adaptation, cultural adaptation, literary adaptation and ideological adaptation. Let us now discuss these types in some detail.

\subsection{Collocation Adaptation}

As previously referred, if a language was simply a nomenclature for a set of universal concepts, it would be easy to translate from one language into another. One would simply replace an English word for a concept with the Arabic name equivalence, for example, or vice versa. Learning a new language would also be much easier than it is. But, as a matter of fact, each language articulates or organizes the world differently and languages all over the world do not simply name existing categories, but they articulate their own.

Collocation can be defined as the way in which words are used together regularly. (Richards, et. al. 1992). It indicates to the restrictions on how words can be used together, for example, prepositions are used with particular verbs, or which verbs and nouns are used together.

It is well-known that collocation is a difficult factor for anyone learning a foreign language. There seems to be no reason for certain collocations. Regular dictionaries are of little help in translating collocations, thus the translator often has to resort to adaptation. For example, the verb perform is used with (collocates with) operation, but not with discussion. So we say: (The doctor performed the operation) but we cannot say * (The committee performed a discussion) since held or had not perform collocates with discussion.

Consequently, we say (The committee held / had a discussion). Another example, the English phrase (dry cow), which is correctly rendered in Arabic as (The cow which stopped providing milk) because literal translation (baqaraton gafaton) would perplex the target language 


\section{International Journal of Science and Research (IJSR) \\ ISSN (Online): 2319-7064}

Index Copernicus Value (2013): 6.14 | Impact Factor (2014): 5.611

receptor (here, the one who speaks Arabic), causing communication to fail.

One more thing, whenever both of the source language and the target language belong to different family languages such as English and Arabic, the rely on adaptation increases and vice versa.

\subsection{Cultural Adaptation}

Culture is a broad term that may cover many things related to people's life. It may be defined as the total set of beliefs, attitudes, customs, behaviors, social habits, etc. of the members of a particular society. Richards, et al (1992). I might confess that the present study can all be covered in one word which is cultural adaptation.

It is also well-known that a translator is bicultural as well as bilingual. That means he / she is the bridge not only between two languages but also between two cultures. In other words, a translator must take into his / her account the target text culture as well as the target text structure. The only means for doing such a thing is applying the techniques of adaptation. To make the point clear, I give the example of the two cultures: The Arab culture and the western culture. The Arab national character by their nature and culture do not speak directly, unlike the westerner who speaks openly and directly. A translator or even an interpreter should take this into consideration while translating or interpreting from English into Arabic or vice versa. Otherwise, there will be what is called a cultural shock. In addition to this, it might be stated that a dispraise in one culture can be a praise in another. To make the point clearer, I might give a funny example with my Ph.D. supervisor when he once told me "Your mother is a cow!!!!!!" At the beginning, I was irritated and terribly shocked since names of animals in general and cow in particular in Arabic cultureis used to dispraise people. But, then I recognized that my dear professor didn't mean it, but he meant to praise my mother for her good education she gave for me. He is Hindu. It's well-known that in Hindu culture Cows are holly and dignified.

\subsection{Literary Adaptation}

This type of adaptation is found in translating pieces of literature such as novel, short story, drama or poetry. Here, the translator hastaken into consideration the cultural divergence while translating a piece of literature from one language into another. For example, translating the title of Hemingway's masterpiece The Old Man and the Sea into

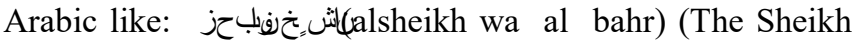
and the Sea) rather than the literal conversion: انكجزنفحز (al'gooz wa al bahr) while the former term (sheikh) in Arabic indicates to many dimensions of the protagonist Santiago, the old man, such as experience, faith, determination and backbone, the latter, (old) does not cover all these dimensions but refers only to old age.

The same for poetry, though poetry is believed to be untranslatable. The old Romans indicate that a translator is a traitor in poetry. Aljahiz once state that rendering poetry is not allowed. All translation theorists are in agreement that poetry is technically untranslatable. But, adaptation can offer help in this aspect and of paramount significance.

Literary adaptation becomes a skill instead of a basic requirement. A good poetry translator instinctively knows the difference between the aesthetic traditions of different cultures, so his / her translation can be better appreciated by the target reader and can achieve the required effect. Otherwise, the translation is doomed to be a failure no matter how close or similar it looks to the original.

Shi (2003) gives an example of Wan Rongpei who is a senior translator, who changed the original Chinese image to be adapted to the English aesthetic tradition when he translated a poem in the ancient poetry collection generally known as The Book of Songs. The ancient Chinese used the following simile to depict a beautiful girl. (Literally translated): "her hands are like soft sprouts; her skin, condensed cream; her neck, lava of a scarab; her teeth, deviltree; her head, qing (a cicada-like insect); and her brows, the shape of a moth. Let us not inquire about the reasons why the ancient Chinese made such comparisons or analogy. But one thing is certain: Westerners would not be able to appreciate such a beautiful girl.

Wang's version, after applying the literary adaptation, reads like this:

Her hands are small, her fingers slim; her skin is smooth as cream; her swan-like neck is long and slim; her teeth like pearls do gleam. A broad forehead and arching brow complement her dimpled cheeks and make her eyes glow. (Shi, 2003).

\subsection{Ideological Adaptation}

By the term Ideological Adaptation I mean sexual and religious concerns. Most Arabs, even today are preserved in dealing with sexual and religious concerns. They avoid the topics of sex, which is usually considered pornography. If you do not, you will be regarded immoral, dishonest, unreliable and simply bad. This is one of the principle reasons why sex education is in school or even in university curriculum but never seriously taught. The teacher just tells the students to read what is written in the textbook and discourages the students from asking and discussing. So in translation, we as translators, either omit or abbreviate the original sex scene of the source text. Translators often edit the language or the scene, or make it implicit instead. In English - Arabic translation, the translator would always make adaptation to soften the original tone, hopping not to offend the target text readers as well as to escape censorship. This does not mean that Arab literature, especially the old one in the pre-Islamic age, never touches upon sex.

Finally, the other topic that needs to throw a light on is the religious writings, especially those who attack Judaism, Christianity or Islam. Let us assume, and this really happens occasionally, a foreign magazine carries offensive topics against Islam and its prophet, Mohammed, peace be upon him. Some might say no need to translate them at all, others are on the opposite side and say a translator should translate everything in detail honestly without hiding anything, 


\section{International Journal of Science and Research (IJSR) \\ ISSN (Online): 2319-7064}

Index Copernicus Value (2013): 6.14 | Impact Factor (2014): 5.611

simply because this is his / her job which is to express others opinions not his / her own.

If the first opinion is to be followed and never translated such writings, then we shall not be able to reply against the aggressive writings, and in case the second opinion to be followed which is to translate everything in detail, this may offend the target receptors and may lead intoa religious conflict. The best thing, in my opinion, is to translate the overall idea of the writing and the details not to be translated. In case the translator wants to object the source text author, he / she writes a footnote at the bottom of the page denying the author's information. I remember a book entitled A Place under the Sun written by the Israeli prime minister and the Leekud Party leader Binjamin Nitinyahoo translated into Arabic by Mohamed Odah AL-Dwery and revised by Kalthoom Alsa'dy. In this book the author attacks Mohamed, the prophet of Islam, peace be upon him. The translator did not change or distort or even modify his translation, on the contrary, he translated the book honestly as it is, but when arriving to the points that attack Islam and its prophet, the translator delivered some notes at the bottom of the page that deny what the SL author states.

The book, the translated version, became best seller and gave opportunities to many Arab and even foreign writers to reply against his claims.

\section{Conclusion}

In the above I have discussed the need for adaptation in translation. I suggest that adaptation is also translation even if it means addition or loss of information, explanation, rewriting, or re-creation. Finally, I classified adaptation into four types.

They are as follows:

1) Collocation adaptation.

2) Cultural adaptation.

3) Literary adaptation.

4) Ideological adaptation.

\section{References}

[1] Newmark, P. (1995) A Textbook of Translation. New York: Phoenix ELT.

[2] Nida, E. and Taber, C. (1982) the Theory and Practice of Translation. New York: Brill, Leiden.

[3] Richards, J. Platt, J. and Platt, H. (1992) Longman Dictionary of Language Teaching and Applied Linguistics. Edinburgh: Longman.

[4] Shi, A. (2003) Accommodation in Translation. Shanxi, China. (An article from the net).

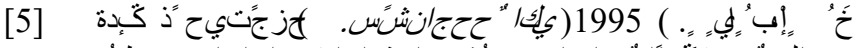

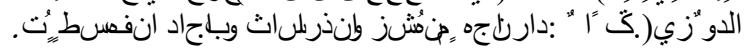

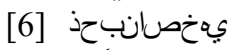

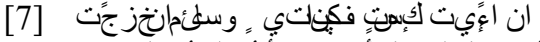

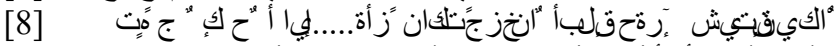

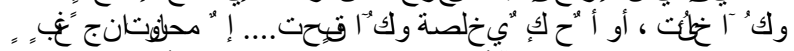

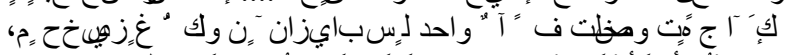

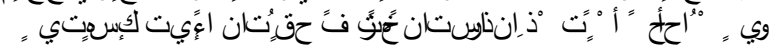

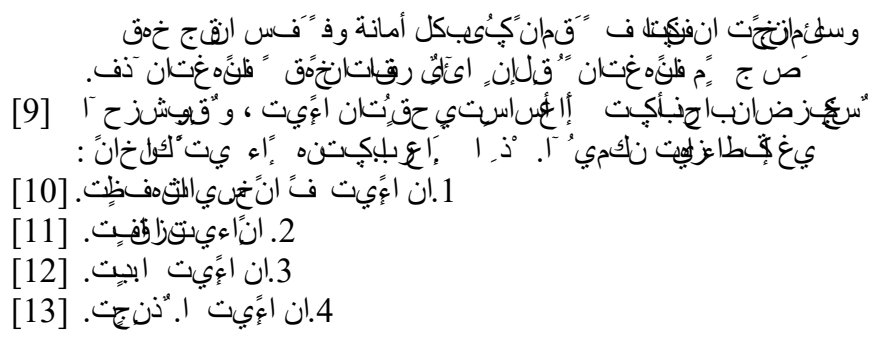

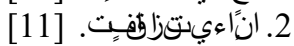

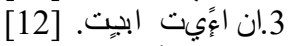

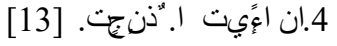

